\title{
Detection of extraneous water adulteration and physico- chemical quality of market milk collected from different areas of Parbhani
}

\author{
A.M. CHAPPALWAR, A.A. DEVANGARE, N.K. KODAMLWAR AND RAJESH KUMAR SAHU
}

\begin{abstract}
Present work was performed to detect extraneous water adulteration in market milk samples collected from four different areas of Parbhani city and to study their effect on physico-chemical quality milk. Milk samples were evaluated for added water, compositional parameters and physic-chemical properties. The results emerged from the study shows that compositional parameters viz., water, total solids, solids not fat, protein, fat, lactose content of milk sample collected from different areas of Parbhani city did not differ significantly, but salt content in milk sample shows significant difference. Similar significant difference was found in physico-chemical properties $i . e$. acidity and $\mathrm{pH}$ of different area milk sample. However freezing point and density of milk sample did not differ significantly. Water adulteration was observed in 36, 76, 64, 32 per cent market milk samples of A, B, C, D areas in Parbhani city, respectively. Addition of extraneous water in milk sample of area A significantly differ $(\mathrm{P}<0.05)$ from $\mathrm{C}$ and $\mathrm{D}$ areas of Parbhani city and influence on the physico-chemical quality of milk.
\end{abstract}

KEY WORDS : Market milk, Water addition, Quality of different areas milk, Compositional parameters, Physico-chemical properties

How to CITE THIS PAPER : Chappalwar, A.M., Devangare, A.A., Kodamlwar, N.K. and Sahu, Rajesh Kumar (2014). Detection of extraneous water adulteration and physico-chemical quality of market milk collected from different areas of Parbhani. Res. J. Animal Hus. \& Dairy Sci., 5(2) : 109112 .

\footnotetext{
Address for correspondence :

A.M. Chappalwar, Department of Livestock Products Technology, College of Veterinary and Animal Sciences, Marathwada Agriculture University Campus, PARBHANI (M.S.) INDIA

Email : anitachappalwar@ rediffmail.com

Associated Authors':

A.A. Devangare and N.K. Kodamlwar, Department of Livestock Products Technology, College of Veterinary and Animal Sciences, Marathwada Agriculture University Campus, PARBHANI (M.S.) INDIA

Rajesh Kumar Sahu, Department of Veterinary Public Health and Epidemiology, College of Veterinary and Animal Sciences, Marathwada Agriculture University Campus, PARBHANI (M.S.) INDIA
} 